\title{
PANDANGAN MAHASISWA PROGRAM STUDI PENDIDIKAN PANCASILA DAN KEWARGANEGARAAN TERHADAP PROFESI PENDIDIK
}

\author{
Neneng Rika Jazilatul Kholidah \\ Fakultas Pendidikan Ilmu Pengetahuan Sosial IKIP PGRI Bojonegoro \\ jazilarika@yahoo.co.id \\ Ernia Duwi Saputri \\ Fakultas Pendidikan Ilmu Pengetahuan Sosial IKIP PGRI Bojonegoro
}

\begin{abstract}
Abstrak
Pendidikan merupakan bidang yang sangat penting bagi kehidupan manusia. Pendidikan dapat mendorong peningkatan kualitas manusia dalam dalam bentuk peningkatan kompetensi kognitif, afektif, maupun psikomotor.Tujuan dilakukan penelitian ini adalah untuk mengetahui pandangan mahasiswa program studi pendidikan pancasila dan kewarganegaraan terhadap profesi pendidik. Penelitian ini dirancang sebagai penelitian deskriptif kualitatif dengan strategi studi kasus tunggal terpancang. Sumber data diperoleh dari subyek penelitian sebagai berikut; 1) Informan/Narasumber, yaitu mahasiswa Program Studi Pendidikan Pancasila dan Kewarganegaraan; 2) Aktivitas mahasiswa ketika berdiskusi terkait profesi seorang pendidik. Teknik pengumpulan data yang digunakan adalah wawancara mendalam, observasi secara langsung dan analisis dokumen. Teknik validitas data menggunakan standar kredibilitas, transferabilitas dan dependibilas dan konfirnabilitas. Teknik analisis data menggunakan metode interaktif. Hasil penelitian dapat disimpulkan bahwa Pandangan mahasiswa terhadap profesi pendidik adalah Profesi pendidik adalah profesi yang terhormat, Eksistensi profesi pendidik di masyarkat menurut mahasiswa Pendidik adalah guru masyarakat,Pendidik sebagai peredam konflik perbedaan budaya dan Profil pendidik ideal menurut mahasiswa dan Alasan mahasiswa memandang profesi pendidik. Guru yang ideal itu tidak mempunyai sifat mementingkan diri sendiri maka guru tersebut bisa dikatakan sebagai guru yang mampu mengerti keinginan anak didik.
\end{abstract}

Kata kunci: Pandangan, Mahasiswa, Profesi Pendidik

\begin{abstract}
Education is a very important field for human life. Education can encourage the improvement of human quality in the form of increasing cognitive, affective, and psychomotor competencies. The purpose of this study was to find out the views of students of Pancasila and citizenship education programs on the teaching profession. This study was designed as a qualitative descriptive study with a single embedded case study strategy. Data sources were obtained from the research subjects as follows; 1) Informants / Resource Persons, namely students of the Pancasila and Citizenship Education Study Program; 2) Student activities when discussing the profession of an educator. Data collection techniques used are in-depth interviews, direct observation and document analysis. The data validity technique uses standards of credibility, transferability and dependability and confirmation. Data analysis techniques use interactive methods. The results of the study can be concluded that the views of students on the teaching profession are teaching professionals is a respectable profession, the existence of the teaching profession in the community according to students Educators are community teachers, educators as dampening conflicts of cultural differences and profiles of ideal educators according to students and reasons students view the teaching profession The ideal teacher does not have selfishness so the teacher can be said to be a teacher who is able to understand the wishes of students.
\end{abstract}

Keywords: Views, Students, Professional Educators

\section{PENDAHULUAN}

Pendidikan merupakan bidang yang sangat penting bagi kehidupan manusia.
Melalui pendidikan dapat mendorong peningkatan kualitas manusia dalam dalam bentuk peningkatan kompetensi kognitif, 
afektif, maupun psikomotor. Masalah yang dihadapi dalam upaya memperbaiki dan meningkatkan kualitas kehidupan sangat kompleks, banyak faktor yang harus dipertimbangkan karena pengaruhnya pada kehidpuan manusia tidak dapat diabaikan. Minat menjadi guru pada jaman dahulu mungkin lebih ditujukan untuk beramal (sikap sosial), karena menjadi guru berarti mengamalkan ilmu dapat mendatangkan pahala. Selain itu guru telah memperoleh perhatian dari pemerintah, terutama dari segi kesejahteraan (Dwi Atmoko,2010 :1). Menjadi seorang guru adalah tantangan besar di era saat ini yang mana seluruh tutur kata dan tingkah laku menjadi sorotan di masyarakat. Guru merupakan tenaga profesioal yang mempunyai tugas mengajar, mendidik dan melatih. Mendidik berarti meneruskan dan mengembangkan nilai-nilai hidup. Guru adalah profesi strategis untuk menuju terciptanya pendidikan yang bermartabat, agar tercipta generasi yang memiliki sumber daya manusia yang handal. Keanehan dan telah menjadi fenomena pada masyarakat bahkan sekolah, pada umumnya siswa cerdas enggan untuk memilih profesi guru. Sebagian guru menganjurkan anak didik yang cerdas agar memilih karir selain guru. Saat anak didik memilih bidang pendidikan dan menjadi mahasiswa, mereka belajar banyak teori tentang pedagogik, psikologi dan perkembangan ilmu-ilmu lain. Setelah menyelesaikan sejumlah mata kuliah dan tugas akhir maka mereka punya hak untuk wisuda dan menyandang predikat S.Pd. (Sarjana Pendidikan) dan berkarir sebagai guru di sekolah. Guru (tenaga pendidik) yang efektif adalah mereka yang berhasil membawa peserta didik mencapai tujuan pembelajaran sesuai dengan kaidah yang berlaku dalam pendidikan. Di dalam dunia pendidikan, guru adalah seorang pendidik, pembimbing dan pengembang kurikulum yang dapat menciptakan kondisi dan sasaran belajar yang kondusif, yaitu suasana belajar yang menyenangkan,menarik, memberi rasa aman, memberikan ruang pada siswa untuk berfikir, kreatif dan inovatif dalam mengeksplorasi dan mengelaborasi kemampuannya (Rusman, 2011: 132).
Pendidikan adalah usaha sadar untuk menyiapkan peserta didik melalui kegiatan bimbingan, pengajaran dan latihan-latihan untuk mempersiapkan kehidupan yang lebih baik dimasa yang akan datang. Orang tua mempercayakan sekolah sebagai suatu lembaga pendidikan untuk mendidik anakanaknya memiliki keterampilanketerampilan, kecerdasan, sebagaimana yang dinyatakan oleh Jejen Musfah dalam bukunya Peningkatan Kompetensi Guru bahwa "Guru harus dapat merancang pembelajaran yang tidak semata menyentuk aspek kognitif, tetapi juga dapat mengembagkan keterampilan dan sikap siswa. Maka guru haruslah individu yang kaya pengalaman dan mampu memtransformasikan pengalamannya itu pada para iswa dengan cara-cara yang variatif"'(Jejen Musfah, 32 : 2011). Walaupun manusia sudah memiliki potensi untuk belajar, maka sebagai guru harus menguasai materi pembelajaran, menyampaikan pengajaran denga teoat dan menangani permasalahan murid dengan tepat pula,atau dengan perkataan lain guru harus cerdas dan terampil dalam kegiatan pembelajaran. Guru harus mempunyai kompetensi dalam mendidik sehingga akan menghasilkan anak didik yang berkualitas , maka kompetensi yang harus dimiliki guru. Seorang guru menjadi pendidikan berarti sekaligus menjadi pembimbing. Sebagai contoh guru yang berfungsi sebagai pendidik dan pengajar seringkali akan melakukan pekerjaan bimbingan, misalnya bimbingan belajar, bimbingan tentang keterampilan dan sebagainya. Jadi guru yang jelas dalam proses pendidikan kegiatan mendidik, mengajar, dan bimbingan sebagai suatu hal yang tidak dapat pisah-pisahkan (Sardiman, 141:2012). Dalam hal ini profesi seorang guru saat ini menjadi topik yang hangat dan selalu diperbincangkan di kalangan masyarakat khususnya jurusan PPKn yang sebagian masyarakat beranggapan bahwa jurusan tersebut menjenuhkan, Tujuan dilakukan penelitian ini adalahuntuk mengetahui pandangan mahasiswa program studi pendidikan pancasila dan kewarganegaraan terhadap profesi pendidik. 


\section{METODE PENELITIAN}

Penelitian dilaksanakan di Program studi Pendidikan Pancasila dan Kewarganegaraan Fakutltas Pendidikan dan Ilmu Pengetahuan Sosial IKIP PGRI BOJONEGORO. Penelitian kualitatif adalah penelitian yang bermaksud untuk memahami fenomena tentang apa yang dialami oleh subjek penelitian, misalnya perilaku, persepsi, motivasi, tindakan, dll,secara holistik dan dengan cara deskripsi dalam bentuk kata-kata dan bahasa, pada suatu konteks khusus yang alamiah dan dengan memanfaatkan berbagai metode alamiah (Lexy J. Meleong, 2007 :6). Strategi yang digunakan dalam penelitian ini sesuai dengan bantuk penelitian dan permasalahan yang telah dirumuskan, yaitu menerapkan pendekatan tunggal terpancang. tunggal dalam arti hanya ada satu lokasi yaitu Program Studi Pendidikan Pancasila dan Kewarganegaraan Fakultas Pendidikan dan Ilmu Pengetahuan Sosial IKIP PGRI BOJONEGORO, sedangkan terpancang pada tujuan penelitian maksudnya apa yang harus diteliti, dibatasi pada aspek-aspek yang sudah dipilih sebelumnya melaksanakan penelitian lapangan.

Dalam penelitian ini akan memilih informan yang benar-benar mengetahui permasalahan, sehingga diperoleh data yang objektif. Informasi yang dipilih adalah mahasiswa Pendidikan Pancasila dan Kewarganegaraan Fakultas Keguruan dan Ilmu Pendidikan IKIP PGRI BOJONEGORO. Pengambilan sampel pada purposivesampling tidak ditekankan pada jumlah melainkan pada kualitas pemahaman masalah yang akan diteliti. Dalam masalah in cenderung dipilih informan yang dianggap tahu dan dapat dipercaya sebagai sumber data. Untuk menguji validitas data peneliti menggunakan trianggulasi sumber Trianggulasi sumber bisa menggunakan satu jenis dan misalnya informan atau narasumber yang digunakan harus merupakan kelompok atau tingakatan yang berbeda-beda. Data yang diperoleh melalui sumber kemudian dilakukan keabsahannya melalui teknik trianggulasi antar sumber.
Hal ini dilakukan dengan cara membandingkan hasil wawancara antara informan yang satu dengan informan yang lain. Teknik analisa data yang digunakan dalam penelitian ini adalah analisis interaktif (interactive model of analysis). Analisis interaktif yaitu suatu model pengumpulan data yang merupakan suatu proses siklus Proses analisis interaktif, ada tiga komponen yang harus disadari sepenuhnya oleh peneliti (H.B. Sutopo, 2002): (1) Reduksi data (Reduction data) adalah bagian dari analisis, suatu bentuk analisis yang mempertegas, memperpendek, membuat, fokus, membuang hal yang tidak penting dan mengatur data sedemikian rupa sehingga kesimpulan akhir data dilakukan, (2) Sajian data (Data dispaly) merupakan suatu rakitan organisasi informasi yang memungkinkan kesimpulan riset dapat dilakukan. Salah satu cara yaitu dengan membuat suatu matrik yang isinya dibuat menurut kebutuhan sesuai aspek yang ingin dimunculkan dan dinampakkan, (3) Penarikan kesimpulan (Conclusion drowing), merupakan langkah analisis data yang dilaksanakan segera setelah data diperoleh. Kesimpulan yang diambil kemungkinan itu perlu dicarai data yang dapat mendukung kesempurnaan kesimpulan dengan cara verifikasi. Yang dimaksud dengan verifikasi adalah mencari data-data baru untuk menguatkan kesimpulan yang telah diambil.

\section{HASIL DAN PEMBAHASAN Pandangan Mahasiswa Terhadap Profesi Pendidik}

Profesi pendidik diantara profesi yang lain dalam masyarakat membuat masyarakat memberikan beberapa penilaian dan selalu membanding-bandingkan dengan profesi lain,Setiap profesi pasti memiliki karakteristik sendiri yang sesuai dengan bidangnya masing-masing. Keberadaan profesi ditengah masyarakat tidak terlepas dari berbagai pandangan dari masyarakat dari berbagai sudut pandang yang berbedademikian pandangan mahasiswa terhadap profesi pendidik : 1) Profesi pendidik adalah profesi yang terhormat karena seorang pendidik mempunyai peranan sangat penting dan sangat 
berpengaruh terhadap anak didiknya; 2) Profesi pendidik adalah profesi yang multidimensional karena tugas seorang pendidik tidak hanya mendidik saja namun juga melaksanakan tugas kemanusiaan dan tugas kemasyarakatan; 3) Profesi pendidik adalah profesi yang rawan tercemar karena saat ini banyak sekolah yang merekrut guru yang bukan berlatar belakang pendidik; 4) Profesi pendidik adalah profesi yang kurang diminati oleh masyarakat karena kurang seimbangnya gaji seorang guru.Eksistensi profesi pendidik di masyarkat menurut mahasiswa.Bahwa tugas guru tidak hanya sekedar mengajarkan ilmu saja namun mempunyai banyak tugas dinas dan diantara juga terdapat tugas kemasyarakatan, guru punya posisi penting di kalangan masyarakat,dalam hal ini Mahasiswa beranggapan bahwa guru bukan hanya sekedar mengajar dikelas saja namun juga memberikan contoh yang baik untuk masyarkat,mengapa demikian?karena siswa dan siswinya juga pada akhirnya akan masuk dalam ranah masyarakat sehingga mahasiswa memberikan anggapan sebagai berikut; 1) Pendidik adalah guru masyarakat karena seorang pendidik, baik seorang guru maupun seorang dosen adalah public figur yang selama ini dianggap masyarakat sebagai sosok yang mulia, terutama pada sikap dan tutur katanya yang sopan dan santun terhadap masyarkat; 2) Pendidik sebagai peredam konflik perbedaan budaya karena penurutanpenuturan guru serta keberadaan guru dimasyarakat sangatlah penting karena dianggap seseorang yang punya cara pandang yang luas sehingga dianggap mampu meredam konflik perbedaan budaya yang terjadi pada masyarakat.Profil pendidik ideal menurut mahasiswabahwasannya guru ideal menuru mahasiswa adalah seseorang yang memiliki keprofesionalan, mahasiswa mempunyai tipe profil seorang pendidik yang ideal sebagai berikut; 1)Guru yang profesional, memahami dan menerima hal-hal yang berkaitan dengan profesinya serta mampu menjalankan dengan penuh tanggungjawab; 2) Guru yang kreatif yang cara mengajarnya penuh dengan kreatifitas dalam proses kegiatan belajar mengajar yang tidak monoton; 3) Guru penyabar, yaitu guru ideal itu yang punya diwa penyabar dan jiwa penuh dengan kasih sayang; 4) Guru yang tidak mementingkan diri sendiri, yaitu guru yang ideal itu tidak mempunyai sifat mementingkan diri sendiri maka guru tersebut bisa dikatakan sebagai guru yang mampu mengerti keinginan anak didik.Alasan mahasiswa memandang profesi pendidik, bahwa guru pengaruhnya sangat besar terhadap anak didiknya oleh sebab itu tugas guru sangatlah berat karena jika terjadi apa-apa dengan anak didik maka nama gurulah juga ikut tercoreng sehingga disini guru bukan memaksa anak didik namun guru memberikan pembinaan sifat mental dan spiritual. Mahasiswa memberikan nilai positif terhadap profesi pendidik ditunjukkan dengan ; 1) Guru mengabdi tanpa pamrih,yaitu tanggungjawab seorang guru sangatlah besar sehingga disitu guru diposisikan dalam posisi yang terhormat karena memiliki jiwa seperti pahlawan; 2) Guru haruslah memiliki kualifikasi seorang guru, maka guru haruslah guru berlatar belakang strata 1 pendidikan.

\section{SIMPULAN}

Berdasarkan penjelasan diatas dapat disimpulkan bahwa; 1) Pandangan mahasiswa terhadap Profesi pendidik adalah profesi yang terhormat karena seorang pendidik mempunyai peranan sangat penting dan sangat berpengaruh terhadap anak didiknya, Profesi pendidik adalah profesi yang multidimensional karena tugas seorang pendidik tidak hanya mendidik saja namun juga melaksanakan tugas kemanusiaan dan tugas kemasyarakatan,Profesi pendidik adalah profesi yang rawan tercemar karena saat ini banyak sekolah yang merekrut guru yang bukan berlatar belakang pendidik, Profesi pendidik adalah profesi yang kurang diminati oleh masyarakat karena kurang seimbangnya gaji seorang guru; 2) Eksistensi profesi pendidik di masyarkat menurut mahasiswa Pendidik adalah guru masyarakat,Pendidik sebagai peredam konflik perbedaan budaya karena penurutan-penuturan guru serta keberadaan guru dimasyarakat sangatlah penting 
karena dianggap seseorang yang punya cara pandang yang luas sehingga dianggap mampu meredam konflik perbedaan budaya yang terjadi pada masyarakat; 3) Profil pendidik ideal menurut mahasiswa dan Alasan mahasiswa memandang profesi

\section{DAFTAR PUSTAKA}

Dwi Atmoko. 2010. Sikap Mahasiswa Pada Profesi Guru dalam Menunjang Kemandirian Belajara Mahasiswa Program Studi Bimbingan Konseling Fkip Universitas Slamet Riyadi Surakarta.

Jejen Musfah. 2011. Peningkatan Kompetensi Guru Melalui Pelatihan dan Sumber Belajar Teori dan Praktik. Jakarta. Kencana Prenada Media Group.

Kusnandar. 2011. Guru Profesional. Jakarta. Rajawali Pers.

Lexy J. Moleong. 2007.Metodologi Penelitian Kualitatif .Bandung : PT Remaja Rosdakarya.

Nana Sudjana. 1989. Dasar-proses Belajar Mengajar. Sinar Baru. Bandung.

Moh. Uzer. 2011. Menjadi Guru Profesional. Jakarta. PT Remaja Rosdakarya. pendidik. Guru yang ideal itu tidak mempunyai sifat mementingkan diri sendiri maka guru tersebut bisa dikatakan sebagai guru yang mampu mengerti keinginan anak didik.

Sardiman. 2012. Interaksi \& Motivasi Belajar Mengajar. Jakarta. Raja Grafindo Persada.

Slameto. 1991. Belajar dan Faktor-faktor yang Mempengaruhinya. Rineka Cipta. Bandung.

Supardi. 2013. Sekolah Efektik. Jakarta. PT Raja Grapindo.

Suyanto. 2013. Menjadi Guru Profesional. Jakarta. Esensi.

Rusman. 2011. Model-model Pembelajaran Mengembangkan Profesionalisme. Jakarta. Rajawali Pers.

Udin Syaifuddin Saad. 2008.Pengembangan Profesi Guru. Alfabeta. Bandung.

Wina Sanjaya. 2008. Strategi Pembelajaran Berorientasi Standar Proses. Kencana. Jakarta.

Wiji Suwarno. 2006. Dasar-Dasar Ilmu Pendidikan. Yogyakarta :Ar-Ruzz Media 